\title{
Clinical evaluation of oxprenolol in angina pectoris
}

\author{
G. Sandler and A. Pistevos \\ From the District General Hospital, Barnsley, Yorks
}

A controlled double-blind clinical evaluation of oxprenolol, a new beta-adrenergic blocking drug, has been carried out in 13 patients with angina pectoris. Objective assessment was based on exercise on a treadmill with continuous radiocardiographic monitoring. The dose of oxprenolol was $80 \mathrm{mg}$ three times a day. There was a significant reduction of the degree of ischaemic ST depression during exercise after oxprenolol treatment, though the amount of exercise was unchanged. It is possible that larger doses of oxprenolol may be of more value in improving exercise tolerance, as well as myocardial ischaemia.

Sympathetic beta-blocking agents are now widely used in the treatment of angina pectoris. Propranolol is the drug with which most experience has been obtained (Gillam and Prichard, I965; Birkett and Chamberlain, 1966; Grant et al., 1966; Sandler, Clayton, and Thornicroft, 1968), but has two important disadvantages - an adverse effect on myocardial function (Chamberlain, 1966; Stephen, I966) and the production of bronchospasm (McNeill, 1964). Oxprenolol, a new betaadrenergic blocking agent, has been found to be equipotent with propranolol, but is claimed to produce significantly less depression of myocardial contractility (Grandjean and Rivier, 1968; Nayler, Chipperfield, and Lowe, 1969), and to have a reduced risk of producing bronchospasm (Beumer, 1969). Favourable clinical and haemodynamic effects were found with intravenous oxprenolol in anginal patients (Sharma et al., I97I), but to date long-term studies of the oral preparation in angina have been based on subjective data only (Scebat and Bensaid, 1970; Bianchi, Lucchelli, and Starcich, 1969; Wilson et al., 1969; Waal, 1968). In view of its potential value in treating angina pectoris it was decided to carry out a controlled doubleblind study of oxprenolol in angina, basing the assessment primarily on objective criteria of ischaemia provided by exercise tolerance tests on a treadmill with continuous radiocardiographic monitoring during the exercise.

Received 24 November 1971 .

\section{Patients and methods}

Thirteen patients with typical angina pectoris, aged 40 to 66 years, were studied. There were Io men and 3 women. Myocardial infarction had occurred in only one patient previously and no patient was suffering from right or left ventricular failure, currently or had done so in the past. In all patients the angina had settled down to a stable pattern; the frequency of angina was up to 7 attacks per week in 7 of the subjects, up to 20 per week in 3, and up to 35 per week in 3, for which glyceryl trinitrate was being taken regularly. All patients showed ST depression in the exercise electrocardiogram, ensuring that an objective index of myocardial ischaemia was available for drug evaluation. The oxprenolol was given in an oral dose of $80 \mathrm{mg}$ three times a day and matched with an identical placebo, each drug being given for a period of one month on a double-blind basis, the choice of the starting drug being randomized.

All patients attended the out-patient department monthly. After a preliminary control period of one month during which the only drug taken was glyceryl trinitrate, the patients were issued with a month's supply of either oxprenolol or placebo, and at the next visit a month later they were given the other drug. A record card was also issued at each visit to be completed daily indicating only the number of attacks of angina experienced that day. The number of anginal attacks was then noted at the subsequent visit, but to eliminate any errors from a carry-over effect of the previous month's therapy only the last two weeks of the four-week period were used to obtain the incidence of anginal attacks.

Exercise tolerance tests were carried out at the beginning of the study and at each of the two subsequent monthly visits. A treadmill was used at 
a speed of 3 m.p.h. and an inclination of $10^{\circ}$. The patient was monitored continuously during the exercise by radiotelemetry and exercise was stopped if the patient developed angina or the radiocardiogram showed ischaemic ST depression. Depression of the ST segment of plane or sagging contours lasting at least $0.08 \mathrm{sec}$ was accepted as indicating myocardial ischaemia (Bellet et al., I962). Radiocardiographic monitoring was continued after cessation of exercise until all evidence of ischaemia had disappeared. The indices of assessment recorded during the exercise test included the duration of exercise before the development of angina or ischaemia, the duration of angina, the degree and duration of the ST depression, and the heart rate before and after exercise. The standing and lying blood pressure was recorded before exercise was started to determine whether the previous month's preparation had a hypotensive action.

In addition to exercise electrocardiography each patient had respiratory function assessed by Vitalograph. The forced expiratory volume at one second and the forced mid-expiratory flow (middle $50 \%$ of the forced vital capacity) were used to assess bronchospasm (Leuallen and Fowler, 1955). Other routine screening investigations included haemoglobin, white count, platelet count, blood urea, and liver function tests.

\section{Results}

In view of the well-established placebo response in anti-angina trials (Greiner et al., 1950), the effects of oxprenolol were assessed solely by comparison with the placebo period. Assessment is based on a statistical analysis of the differences occurring in individual patients, and not by comparison of the mean values of the two groups as a whole, as this affords a more sensitive index of drug response. The results are shown in the Table. There was no significant change in the weekly incidence of angina after oxprenolol treatment. Nor were there any significant differences in either the duration of exercise or the duration of exercise-induced angina. However, when the more objective indices of myocardial ischaemia are considered, it is seen that oxprenolol has produced a significant decrease in the amount of ST depression produced during exercise $(P<0.02)$ though the duration of this depression was not influenced. Both the resting heart rate $(P<0.02)$ and the heart rate after exercise $(P<0.001)$ were significantly lower with oxprenolol. The effect of oxprenolol on blood pressure is also shown in the Table, and here the only significant finding was a fall in standing systolic pressure $(\mathbf{P}<0.02)$. Assessment of respiratory function showed a reduction of FEV 1.0 with oxprenolol which was statistically but not clinically significant.

There was no evidence of any adverse effects of oxprenolol on the routine haematological screening tests.

\section{Discussion}

Oxprenolol has been found to be a potent beta-receptor blocker both experimentally

TABLE Comparison of clinical, electrocardiographic, and respiratory parameters between placebo and oxprenolol in 13 anginal patients

\begin{tabular}{|c|c|c|c|c|c|}
\hline & \multicolumn{2}{|c|}{$\begin{array}{l}\text { Mean values of whole } \\
\text { group }\end{array}$} & \multirow{2}{*}{$\begin{array}{l}\text { Mean differ- } \\
\text { ence between } \\
\text { placebo and } \\
\text { oxprenolol }\end{array}$} & \multirow{2}{*}{$\begin{array}{l}\text { Standard } \\
\text { error of } \\
\text { mean } \\
\text { difference }\end{array}$} & \\
\hline & Placebo & Oxprenolol & & & \\
\hline $\begin{array}{l}\text { No. of anginal attacks per week } \\
\text { Exercise test }\end{array}$ & II $\cdot 8$ & 10.4 & $-1 \cdot 4$ & $2 \cdot 07$ & NS \\
\hline $\begin{array}{l}\text { Duration of exercise (sec) } \\
\text { Duration of angina induced by }\end{array}$ & $131 \cdot 5$ & $136 \cdot 2$ & $+4 \cdot 7$ & 17.9 & NS \\
\hline $\begin{array}{l}\text { exercise (sec) } \\
\text { Amount of ST depression (mm) }\end{array}$ & 213.8 & $185 \cdot 0$ & $-28 \cdot 8$ & $24 \cdot 8$ & NS \\
\hline $\begin{array}{l}\text { during exercise } \\
\text { after exercise }\end{array}$ & $\begin{array}{l}0.7 \\
0.88\end{array}$ & $\begin{array}{l}0.3 \\
0.73\end{array}$ & $\begin{array}{l}-0.38 \\
-0.15\end{array}$ & $\begin{array}{l}0.17 \\
0.19\end{array}$ & $\begin{array}{l}0.02<P<0.05 \\
\text { NS }\end{array}$ \\
\hline Duration of ST depression (sec) & 264 & 264 & 0 & 0 & \\
\hline $\begin{array}{l}\text { Heart rate before exercise } \\
\text { Heart rate after exercise }\end{array}$ & $\begin{array}{r}79 \cdot 5 \\
124 \cdot 1\end{array}$ & $\begin{array}{l}68 \cdot 5 \\
97 \cdot 5\end{array}$ & $\begin{array}{l}-11 \cdot 0 \\
-26.6\end{array}$ & $\begin{array}{l}4 \cdot 0 \\
6 \cdot 0\end{array}$ & $\begin{array}{l}0.01<\mathrm{P}<0.02 \\
<0.001\end{array}$ \\
\hline Systolic blood pressure: lying & $145 \cdot 8$ & $141 \cdot 7$ & $-4 \cdot I$ & 4.7 & NS \\
\hline $\begin{array}{l}\text { Diastolic blood pressure: } \\
\text { lying } \\
\text { standing }\end{array}$ & $\begin{array}{r}145 \cdot 0 \\
86 \cdot 7 \\
86 \cdot 3\end{array}$ & $\begin{array}{r}136 \cdot 7 \\
83 \cdot 3 \\
81 \cdot 3\end{array}$ & $\begin{array}{l}-8 \cdot 3 \\
-3 \cdot 4 \\
-5 \cdot 0\end{array}$ & $\begin{array}{l}4 \cdot 3 \\
3 \cdot 1 \\
2 \cdot 4\end{array}$ & $\begin{array}{l}0.01<P<0.02 \\
\text { NS } \\
\text { NS }\end{array}$ \\
\hline $\begin{array}{l}\text { Respiratory function } \\
\text { FEV }_{1 \cdot 0}(1 .) \\
\text { FMF (1./min) }\end{array}$ & $\begin{array}{r}2 \cdot 6 \\
123 \cdot 0\end{array}$ & $\begin{array}{r}2 \cdot 4 \\
123 \cdot 5\end{array}$ & $\begin{array}{l}-0.2 \\
+0.5\end{array}$ & $\begin{array}{l}0.07 \\
7.6\end{array}$ & $\begin{array}{l}0.01<\mathrm{P}<0.02 \\
\mathrm{NS}\end{array}$ \\
\hline
\end{tabular}

$\mathrm{FEV}_{1 \cdot 0}=$ forced expiratory volume at $\mathrm{I}$ sec $; \mathrm{FMF}=$ forced mid-expiratory flow; $\mathrm{NS}=$ Not significant. 
(Bender, 1968) and in man (Grandjean and Rivier, 1968). It has been found to produce significantly less depression of myocardial contractility in therapeutic doses than propranolol (Grandjean and Rivier, I968; Nayler et al., 1969) probably due to its inherent sympathomimetic activity (Brunner, Hedwall, and Meier, 1968), a property not possessed by propranolol.

The favourable reports to date from controlled studies of oral oxprenolol in angina have been largely subjective and based on alterations in the frequency and severity of the anginal attacks (Scebat and Bensaid, -1970; Bianchi et al., 1969; Wilson et al., 1969; Pitt and Anderson, 1970). Subjective studies are of limited value in clinical evaluation of an anti-anginal drug. Most workers have found little correlation between frequency and severity of angina and the degree of myocardial ischaemia (Riseman, Altman, .and Koretsky, 1958; Batterman, I955; Katz, 1935) though others, however (Sharma et al., 197I), using oxprenolol and propranolol intravenously, have shown some correlation. Though the patient's concern is naturally enough with the relief of his angina, it is the physician's responsibility to achieve this by measures which interfere with the painproducing myocardial ischaemia. The necessity for an objective study in assessing the effect of a drug on myocardial ischaemia therefore becomes obvious. The results of the present study confirmed the beneficial effect of oxprenolol on the degree of myocardial ischaemia induced by exercise, but did not show any significant change in amount of exercise possible. The frequency of the angina was not influenced by oxprenolol in the dose used in the study and in this respect practolol has produced similar results (Sandler and Clayton, 1970). The more favourable effects of intravenous oxprenolol on exercise tolerance found by Sharma et al. (1971) and Prichard, Aellig, and Richardson (I970) suggest the possibility of inadequate blood levels of oxprenolol in the present study, either through inadequate oral dosage or possibly defective absorption, a question that can only be decided by measurement of oxprenolol blood levels. However, the slowing of heart rate both before and after exercise following oxprenolol treatment does show a measure of betareceptor blockade. While there were no clinically adverse effects on myocardial function produced by oxprenolol there was an average reduction of $0.21 . / \mathrm{min}$ in the forced respiratory volume at one second suggesting a bronchoconstrictor effect found also with other beta-blocking drugs, such as proprano- lol, when used in treating angina (Sandler and Clayton, 1970).

In the present study oxprenolol has produced a significant improvement in exerciseinduced ischaemic ST depression in a dose of $80 \mathrm{mg}$ three times a day. It is quite possible that larger doses of oxprenolol might result in correspondingly more favourable subjective effects since it has been clearly shown by Prichard and Gillam (197I) that the effectiveness of the beta-blocking drug, propranolol, both in controlling angina and in influencing the electrocardiographic changes during exercise, is progressively related to the dosage used.

We are indebted to Dr. R. Rondel of Ciba for supplies of oxprenolol and placebo.

\section{References}

Batterman, R. C. (1955). Drugs and anginal syndrome. fournal of the American Medical Association, 157, I333.

Bellet, S., Eliakim, M., Deliyiannis, S., and LaVan, D. (I962). Radioelectrocardiography during exercise in patients with angina pectoris. Comparison with the post exercise electrocardiogram. Circulation, 25, 5 .

Bender, F. (1968). Zum Problem der Dosierung bei der Behandlung von Sinustachykardien mit Betarezeptorenblockern. Medizinische Welt (Stuttgart), 2, 2481 .

Beumer, H. M. (1969). Local effects of beta-adrenergic blocking drugs in histamin sensitive asthmatics. Pharmacologia clinica, I, 172.

Bianchi, C., Lucchelli, P. E., and Starcich, R. (1969). Beta-blockade and angina pectoris: a controlled multicentre clinical trial. Pharmacologia clinica, I, I6I.

Birkett, D. A., and Chamberlain, D. A. (1966). Betaadrenergic blockade in angina pectoris. A method of treadmill assessment. British Medical fournal, 2, 500.

Brunner, H., Hedwall, R. R., and Meier, M. (1968). Pharmakologische Untersuchungen mit I-Isopropylamono - 3 - (0 - allyloxyphenoxy) - 2 - propanol hydrochlorid, einem adrenergischenbeta - Receptorenblocker. Arzneimittel-Forschung, 18, 164.

Chamberlain, D. A. (I 966 ). The haemodynamic effects of beta-adrenergic blockade in man. Cardiologia, 49, Suppl. I I, 27.

Gillam, P. M. S., and Prichard, B. N. C. (1965). Use of propranolol in angina pectoris. British Medical fournal, 2, 337.

Grandjean, T., and Rivier, J. L. (I968). Cardiocirculatory effects of beta-adrenergic blockade in organic heart disease. Comparison between propranolol and CIBA 39,089-Ba. British Heart fournal, 30, 50.

Grant, R. H. E., Keelan, P., Kernohan, R. J., Leonard, J. C., Nancekievill, L., and Sinclair, K. (I966). Multicenter trial of propranolol in angina pectoris. American fournal of Cardiology, 18, 361.

Greiner, T., Gold, H., Cattell, M., Travell, J., Bakst, H., Rinzler, S. H., Benjamin, Z. H., Warshaw, L. J., Bobb, A. L., Kwit, N. T., Modell, W., Rothendler, H. H., Messeloff, C. R., and Kramer, M. L. (1950). Method for the evaluation of the effects of drugs on cardiac pain in patients with angina of effort; a study of khellin (visammin). American fournal of Medicine, 9, 143. 
Katz, L. N. (1935). Mechanism of pain production in angina pectoris. American Heart fournal, 10, 322.

Leuallen, E. C., and Fowler, W. S. (1955). Maximal midexpiratory flow. American Review of Tuberculosis, 72, 783.

McNeill, R. S. (1964). Effect of $\beta$-adrenergic-blocking agent, propranolol, on asthmatics. Lancet, 2, I IOI.

Nayler, W. G., Chipperfield, D., and Lowe, T. E. (1969). The negative inotropic effect of adrenergic betareceptor blocking drugs on human heart muscle. Cardiovascular Research, 3, 30.

Pitt, A., and Anderson, S. T. (1970). A comparison of the effects of 'Trasicor' (oxprenolol) and 'Inderal' (propranolol) on left ventricular myocardial function. Medical fournal of Australia, I, 1089.

Prichard, B. N. C., Aellig, W. H., and Richardson, G. A. (1970). The action of intravenous oxprenolol, practolol, propranolol and sotalol on acute exercise tolerance in angina pectoris: the effect on heart rate and the electrocardiogram. Postgraduate Medical fournal, 46, Suppl., 77.

Prichard, B. N. C., and Gillam, P. M. S. (197I). Assessment of propranolol in angina pectoris. Clinical dose response curve and effect on electrocardiogram at rest and on exercise. British Heart Fournal, 33, 473.

Riseman, J. E. F., Altman, G. E., and Koretsky, S. (1958). Nitroglycerin and other nitrites in the treatment of angina pectoris: comparison of six preparations and four routes of administration. Circulation, 17, 22.
Sandler, G., and Clayton, G. A. (1970). Clinical evaluation of practolol, a new cardioselective beta-blocking agent in angina pectoris. British Medical fournal, 2, 399.

Sandler, G., Clayton, G. A., and Thornicroft, S. G. (1968). Clinical evaluation of Verapamil in angina pectoris. British Medical fournal, 3, 224.

Scebat, L., and Bensaid, J. (1970). Long-term clinical results of oxprenolol in the treatment of cardiac arrhythmias, angina pectoris and hypertrophic subaortic stenosis. Postgraduate Medical fournal, 46, Norember Suppl., 86.

Sharma, B., Meeran, M. K., Galvin, M. C., Tulpule, A. T., Whitaker, W., and Taylor, S. H. (I97I). Comparison of adrenergic beta-blocking drugs in angina pectoris. British Medical fournal, 3, 152.

Stephen, S. A. (1966). Unwanted effects of propranolol. American fournal of Cardiology, 18, 463.

Waal, H. J. (1968). Hypotensive, antiarrhythmic and chronotropic action of Trasicor (Ciba 39089-Ba). New Zealand Medical fournal, 67, 291.

Wilson, D. F., Watson, O. F., Peel, J. S., and Turner, A. S. (1969). Trasicor in angina pectoris: a doubleblind trial. British Medical fournal, 2, 155.

Requests for reprints to Dr. G. Sandler, Barnsley District General Hospital, Gawber Road, Barnsley, Yorkshire. 